\title{
HEAT STABILITY OF PROTEIN SOLUTIONS OBTAINED FROM HUMAN PLASMA BY DIFFERENT ETHANOL CONCEN- TRATIONS AND TEMPERATURES ${ }^{1}$
}

\author{
By DWIGHT J. MULFORD AND EDWARD H. MEALEY \\ (From the Department of Biochemistry, University of Kansas, Lawrence, Kan.)
}

(Submitted for publication June 29, 1956; accepted July 18, 1956)

In a previous publication we reported a method for the preparation of a heat stable human plasma protein solution (1). The method was a modification of that of Cohn, Strong, Hughes, Mulford, Ashworth, Melin, and Taylor (2) and used ethanol-water mixtures at low temperatures for the separation of the heat labile crude fibrinogen fraction (Fraction $\mathrm{I}$ ) and gamma globulin fraction (Fraction II + III) from normal human plasma. The supernatant fluid following the removal of the crude gamma globulin fraction was dried from the frozen state and reconstituted to plasma volume with distilled water. Heating of this material for 10 hours at $60^{\circ} \mathrm{C}$. changed the optical density at $550 \mathrm{~m} \mu$ and the electrophoretic distribution very little. Electrophoretically, the heated material was 80 per cent albumin, 16 per cent alpha globulin and 4 per cent beta globulin. Heating of the solution for 10 hours at $60^{\circ} \mathrm{C}$. caused the formation of a small amount of a very fast moving component in the ultracentrifuge. The remainder representing approximately 90 per cent of the starting protein concentration was homogeneous and had an uncorrected sedimentation constant of approximately $4.0 \times 10^{-18}$.

The present communication concerns the heat stability of human plasma protein solutions remaining following the precipitation of the Fraction II + III proteins from normal human plasma by different ethanol concentrations and temperatures.

\section{METHODS AND RESULTS}

Plasma used in this study was furnished by the American Red Cross through its Regional Blood Centers at Omaha, Nebraska and Springfield, Missouri. The plasma was pooled at the Blood Center in two-liter bottles and

1 This investigation was supported in part by research grant (H1229) from the National Heart Institute of the National Institutes of Health, Public Health Service, in part by a grant from the Department of the Army and in part by the University of Kansas. ten liters were shipped to us each week. No attempt was made to keep the plasma cold while en route. At the laboratory the plasma was stored at $-18^{\circ} \mathrm{C}$. until the fractionation procedure was started.

The procedure for separation of the Fraction I and Fraction II + III proteins from human plasma was exactly the same as that described previously (1). Only the ethanol concentration and temperature for separation of the Fraction II + III proteins were changed. At least 8 liters of plasma were used in each preparation by each method. Table I shows the ethanol concentrations and temperatures that were used to separate the Fraction II + III proteins from the supernatant fluid of Fraction I. In all methods except Method $S$ as shown in Table $I$ the crude fibrinogen fraction, Fraction I, was separated from plasma at 8 per cent ethanol, $\mathrm{pH}$ $7.2 \pm 0.2$, ionic strength 0.14 and temperature $0^{\circ} \mathrm{C} . \pm$ $0.5^{\circ} \mathrm{C}$. The supernatant fluid obtained after removal of Fraction II + III by each method was dried from the frozen state. The dry powder was the material used in this investigation.

In all methods except Method $\mathrm{S}$ the $\mathrm{pH}$ and ionic strength for the separation of Fraction II + III were near $6.8 \pm 0.05$ and 0.12 , respectively. In Method $\mathrm{S}$ the $\mathrm{pH}$ and ionic strength were $6.9 \pm 0.05$ and 0.133 , respectively.

\section{The electrophoretic distribution of the plasma pro- tein preparations}

The electrophoretic distribution of the plasma protein preparations obtained by Methods A, B, $\mathrm{C}, \mathrm{F}$, and $\mathrm{S}$ is shown in Table II.

The protein distribution of the plasma protein mixture was determined using the Klett Electrophoresis apparatus. The dry powder obtained by each method was dissolved to protein concentrations of 1 to 2 per cent in veronal citrate buffer of 0.1 ionic strength and $\mathrm{pH} 8.6$ and dialyzed against this buffer.

Table II shows that the plasma protein mixtures prepared by Methods $A, B$, and $C$ were approximately the same electrophoretically. All contained approximately 80 per cent albumin, 13 to 14 per cent alpha globulin, 5.6 per cent beta globulin, no gamma globulin and no fibrinogen. Methods $\mathrm{F}$ and $\mathrm{S}$ preparations showed more alpha and beta 
TABLE I

Ethanol concentrations and temperatures used for the separation of the Fraction $I I+I I I$ proteins

\begin{tabular}{cccc}
\hline \hline Method & $\begin{array}{c}\text { 95 per cent } \\
\text { ethanol } \\
\text { added }\end{array}$ & $\begin{array}{c}\text { Final } \\
\text { ethanol } \\
\text { concentration }\end{array}$ & Temperature \\
\hline & ml./liter* & per cent & C. \\
A & 234 & 25 & $-5 \pm 0.5$ \\
B & 234 & 25 & $0 \pm 0.5$ \\
C & 160 & 20 & $-5 \pm 0.5$ \\
F & 160 & 20 & $0 \pm 0.5$ \\
S & $\dagger$ & 11 & $0 \pm 0.5$ \\
\hline
\end{tabular}

* M1. per liter of the supernatant fluid following separation of Fraction I.

$\dagger 131 \mathrm{ml}$. of 95 per cent ethanol were added directly to each liter of plasma. Fraction I was not removed beforehand.

globulin and contained gamma globulin. Occasionally fibrinogen was present also. The increase in globulin and fibrinogen concentrations resulted in a relative decrease in the electrophoretic concentration of albumin, as albumin was soluble for the most part under the conditions used in all methods studied.

The effect of heating for 10 hours at $60^{\circ} \mathrm{C}$. on the electrophoretic patterns of the plasma protein solutions

The supernatant fluid following the separation of Fraction II + III by each method was clarified by filtration through Hormann $\mathrm{D}-8$ pads, dried from the frozen state and reconstituted to plasma volume with distilled water. Plasma protein solutions containing either added $0.008 \mathrm{M}$ sodium acetyl-DL-tryptophanate (AT) or $0.008 \mathrm{M}$ sodium caprylate (Cap) were prepared also. Both stabilized as well as non-stabilized solutions were prepared such that the $\mathrm{pH}$ was $6.8 \pm 0.2$.

Each solution was sterilized by filtration through Hormann D-3, D-8, and D-10 filter pads placed into sterile Coleman Jr. Spectrophotometer tubes and capped with sterile rubber stoppers. Some of the tubes were heated for 10 hours at $60^{\circ} \mathrm{C}$. while others not heated were used as control tubes. Following heating a few tubes of the heated solution were dried from the frozen state, reconstituted to protein concentrations of 1 to 2 per cent in veronal citrate buffer of 0.1 ionic strength and $\mathrm{pH} 8.6$, dialyzed, and examined in the electrophoresis apparatus. Optical density measurements were made on the remaining tubes. The effect of 10 hours heating at $60^{\circ} \mathrm{C}$. on the electrophoretic patterns is shown in Figure 1. The top row (U) represents the unheated control solutions, the bottom row $(\mathrm{H})$ the solutions heated for 10 hours at $60^{\circ} \mathrm{C}$.

Figure 1 shows that heating the solutions for 10 hours at $60^{\circ} \mathrm{C}$. resulted in the formation of a new electrophoretic component having a mobility close to that of $\alpha_{2}$-globulin. The size of this component was dependent upon the concentration of ethanol and the temperature used in preparation of the plasma protein mixture. Method A solutions had the smallest amount of the new component (Figure $1 \mathrm{AH}$ ) while Method S solutions had the largest amount (Figure $1 \mathrm{SH}$ ).

Except for the large new component the electrophoretic distribution of the proteins in solutions $\mathrm{A}, \mathrm{B}, \mathrm{C}$, and $\mathrm{F}$ following heating for 10 hours at $60^{\circ} \mathrm{C}$. was approximately the same as that of the unheated samples shown in Table II. There were slight reductions in albumin and beta globulin. Those components affected most by heating were the alpha globulins. Electrophoretically the protein distribution in the Method A solutions following heating for 10 hours at $60^{\circ} \mathrm{C}$. was albumin 81.0 per cent, alpha globulin 14.0 and beta globulin 4.2. In both the $B$ and the $C$ solutions

TABLE II

The electrophoretic distribution of the plasma protein preparations obtained by Methods $A, B, C, F$, and $S$

\begin{tabular}{|c|c|c|c|c|c|}
\hline \multirow{2}{*}{$\begin{array}{l}\text { Method and } \\
\text { number of } \\
\text { preparations }\end{array}$} & \multirow{2}{*}{$\begin{array}{l}\text { Approximate } \\
\text { protein yield } \\
\text { per } 100 \mathrm{ml} \text {. plasma }\end{array}$} & \multicolumn{4}{|c|}{ Average electrophoretic distribution } \\
\hline & & Albumin & a-globulin & $\beta$-globulin & $\gamma$-globulin \\
\hline $\begin{array}{ll}\text { A } & 3 \\
\text { B } & 4 \\
\text { C } & 3 \\
\text { F } & 3 \\
\text { S } & 2\end{array}$ & $\begin{array}{c}\text { grams } \\
3.4 \\
3.5 \\
3.9 \\
4.3 \\
4.9\end{array}$ & $\begin{array}{c}\text { per cent } \\
81.6 \\
79.6 \\
80.2 \\
73.6 \\
65.7\end{array}$ & $\begin{array}{c}\text { per cent } \\
12.8 \\
14.6 \\
14.5 \\
18.8 \\
20.1\end{array}$ & $\begin{array}{c}\text { per cent } \\
5.6 \\
5.5 \\
5.3 \\
5.4 \\
4.4\end{array}$ & $\begin{array}{c}\text { per cent } \\
0 \\
* \\
0 \\
2.2 \\
8.8 t\end{array}$ \\
\hline
\end{tabular}

* One preparation was 1.3 per cent in $\gamma$-globulin.

t One preparation was 2.8 per cent in fibrinogen. 

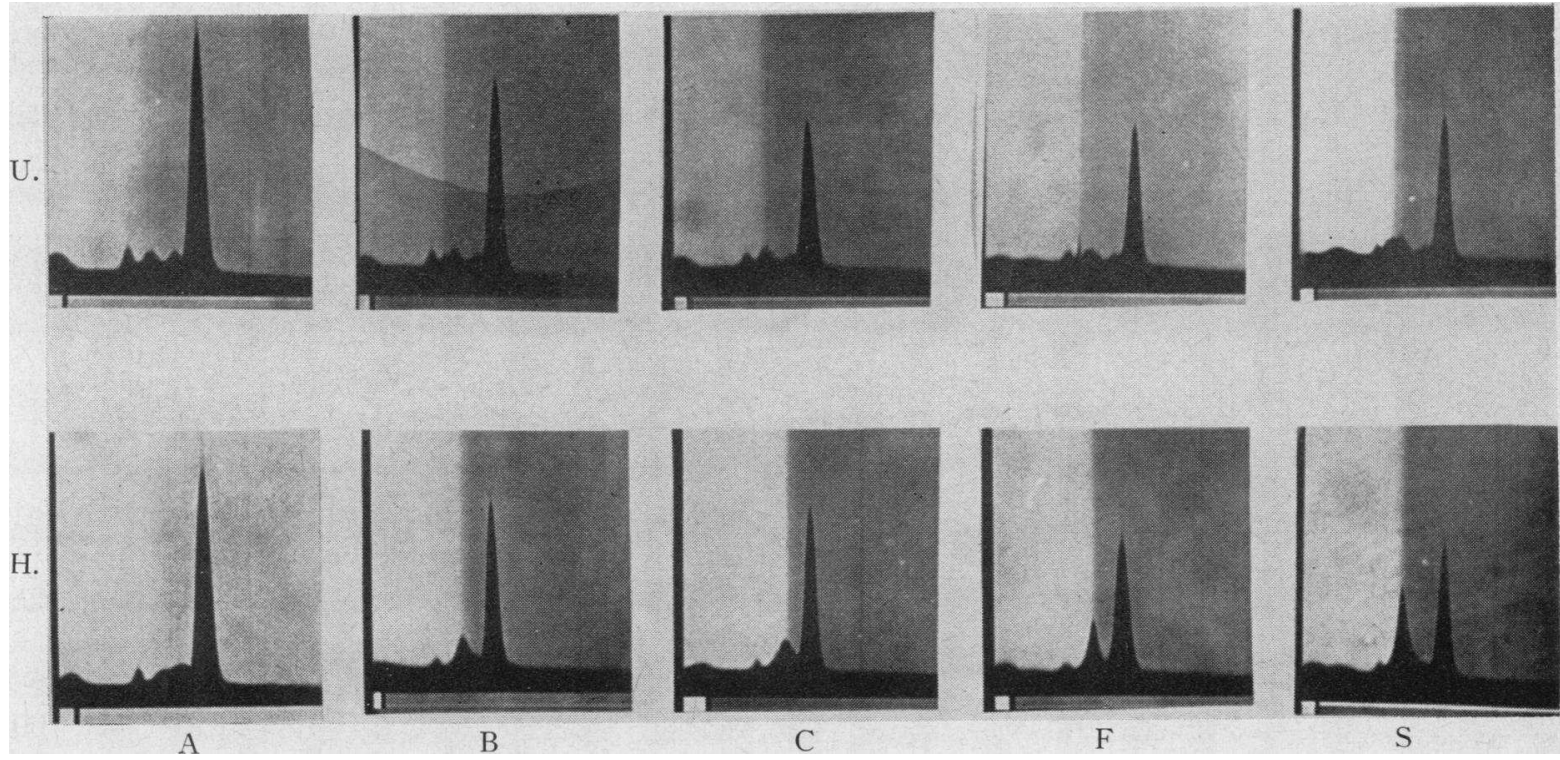

Fig. 1. The Electrophoretic Diagrams of the Plasma Protein Solutions

The upper row (U) represents the unheated solutions, the lower row $(H)$ the solutions heated for 10 hours at $60^{\circ} \mathrm{C}$. Each solution was made to 1 or 2 per cent in protein in veronal citrate buffer of 0.1 ionic strength and $\mathrm{pH}$ 8.6. The pictures above were taken between 120 to 150 minutes after starting the run.

albumin was 70 to 80 per cent, alpha globulin 14 to 24 and beta globulin 3.4. In the $F$ solutions albumin was on the average 71.4 per cent, alpha globulin 23.9 and beta globulin 3.5.

The greatest effect on the electrophoretic distribution following heating for 10 hours at $60^{\circ} \mathrm{C}$. was shown by the Method S solutions. The average protein distribution of the $\mathrm{S}$ material before heating (Table II) was albumin approximately 65.7 per cent, alpha globulin 20.1 , beta globulin 4.4 and gamma globulin 8.4. One preparation was 2.8 per cent in fibrinogen. Following heating of the S solutions albumin was only 32.7 per cent in one solution and 53.3 per cent in the other. Alpha globulin was 40 per cent in one and 63.2 in the other. Beta globulin was approximately 2.2 per cent and gamma globulin 2.9 per cent in both solutions.

The addition of either $0.008 \mathrm{M}$ sodium acetylDL-tryptophanate or $0.008 \mathrm{M}$ sodium caprylate had little effect on the electrophoretic patterns of any of the solutions heated for 10 hours at $60^{\circ} \mathrm{C}$. In many solutions there was an indication that acetylDL-tryptophanate did reduce the amount of the new component due to heating the solutions for 10 hours at $60^{\circ} \mathrm{C}$. Both acetyl-DL-tryptophanate and caprylate have been demonstrated to be ef- fective stabilizers of normal human albumin $(3,4)$.

The effect of heating for 10 hours at $60^{\circ} \mathrm{C}$. on the optical density of the plasma protein solutions

Optical density readings of both the heated and control tubes were made at $550 \mathrm{~m} \mu$ in the Coleman Jr. Spectrophotometer. The optical density

TABLE III

The effect of heating the plasma protein solutions for 10 hours at $60^{\circ} \mathrm{C}$. at $\mathrm{pH} 6.8$ on the optical density at $550 \mathrm{m \mu}$

\begin{tabular}{|c|c|c|c|c|}
\hline \multirow{2}{*}{$\begin{array}{c}\text { Method } \\
\text { and } \\
\text { number } \\
\text { of prepa- } \\
\text { rations }\end{array}$} & \multirow[b]{2}{*}{ Stabilizer } & \multicolumn{2}{|c|}{$\begin{array}{l}\text { Average optical density } \\
\text { at } 550 \mathrm{~m} \mu\end{array}$} & \multirow{2}{*}{$\begin{array}{l}\text { Average } \\
\text { optical } \\
\text { density } \\
\text { change } \\
\text { due to } \\
\text { heating }\end{array}$} \\
\hline & & $\begin{array}{c}\text { Un- } \\
\text { heated }\end{array}$ & $\begin{array}{l}\text { Heáted } \\
10 \mathrm{hrs} \text {. } \\
\text { at } 60^{\circ} \mathrm{C} .\end{array}$ & \\
\hline A 3 & None & 0.192 & 0.200 & 0.008 \\
\hline 3 & AT & 0.200 & 0.206 & 0.006 \\
\hline 3 & Cap & 0.186 & 0.184 & -0.002 \\
\hline B 4 & None & 0.177 & 0.195 & 0.018 \\
\hline 4 & $\mathrm{AT}$ & 0.168 & 0.185 & 0.017 \\
\hline 4 & Cap & 0.169 & 0.177 & 0.008 \\
\hline C 3 & None & 0.241 & 0.259 & 0.018 \\
\hline 3 & $\mathrm{AT}$ & 0.263 & 0.285 & 0.022 \\
\hline 3 & Cap & 0.216 & 0.254 & 0.038 \\
\hline F 3 & None & 0.234 & 0.276 & 0.042 \\
\hline & $\mathrm{AT}$ & 0.249 & 0.293 & 0.044 \\
\hline 3 & Cap & 0.204 & 0.280 & 0.076 \\
\hline S 2 & None & 0.365 & 0.473 & 0.108 \\
\hline
\end{tabular}


values shown in Table III are average values for the number of preparations made by each method. For each preparation between 15 and 30 Coleman $\mathrm{Jr}$. tubes of unheated solution and between 40 and 60 tubes of heated solution were read at $550 \mathrm{~m} \mu$ in the Coleman Jr. Spectrophotometer. Table III shows the effect of heating the plasma protein solutions for 10 hours at $60^{\circ} \mathrm{C}$. on the optical density at $550 \mathrm{~m} \mu$.

The optical density changes due to heating at $60^{\circ} \mathrm{C}$. for 10 hours indicate that the plasma protein solutions of Methods A, B, and C were approximately the same. Table III shows that following heating at $60^{\circ} \mathrm{C}$. for 10 hours solution $\mathrm{A}$ increased in optical density from 0.192 to 0.200 , solution $B$ from 0.177 to 0.195 and solution $C$ from 0.241 to 0.259 . Solutions prepared by Method F showed an optical density change due to 10 hours heating at $60^{\circ} \mathrm{C}$. of 0.042 . On gross examination following heating the $\mathrm{F}$ and $\mathrm{S}$ solutions were noticeably more hazy than the $\mathrm{A}, \mathrm{B}$, and $\mathrm{C}$ solutions.

The difference in initial optical density readings (Table III) may be explained partially by the protein concentrations (Table II). Since each solution was made to plasma volume, the A, B, C, $\mathrm{F}$, and $\mathrm{S}$ solutions were approximately $3.4,3.5$, $3.9,4.3$, and 4.9 per cent in protein, respectively, as measured by the biuret method (5). Whether the change in optical density due to heating the solutions for 10 hours at $60^{\circ} \mathrm{C}$. can be explained by difference in protein concentration has not been demonstrated conclusively. When 5, 6, and 7 per cent protein solutions were prepared from Method A material, the optical density changes following heating were only $0.01,0.03$, and 0.035 respectively. Method S solutions changed from an initial optical density of 0.365 to 0.473 or 0.108 on heating for 10 hours at $60^{\circ} \mathrm{C}$.

The addition of either $0.008 \mathrm{M}$ sodium acetylDL-tryptophanate (AT) or $0.008 \mathrm{M}$ sodium caprylate (Cap) as stabilizers had little effect on the optical density change of solutions heated for 10 hours at $60^{\circ} \mathrm{C}$ (Table III). The optical density changes of solutions containing these substances were about the same as those containing no added stabilizer. Preliminary evidence (6) indicates that both tryptophanate and caprylate were effective in solutions heated for at least 75 hours at $60^{\circ} \mathrm{C}$. Solutions containing no added stabilizer and heated at $60^{\circ}$ for 75 hours or more showed a greater change in optical density than did the same solutions containing either added tryptophanate or caprylate.

\section{The effect of heating for 10 hours at $60^{\circ} \mathrm{C}$. on the ultracentrifugal sedimentation diagrams of the plasma protein solutions}

Heated and unheated samples of plasma protein solutions prepared by Methods A, B, C, F, and $\mathrm{S}$ were studied in the Spinco Ultracentrifuge Model E. Each solution was diluted with $0.15 \mathrm{M}$ $\mathrm{NaCl}$ such that the protein concentration was approximately 1.0 per cent. For each solution the heated and unheated samples were run at the same time using both cells of the rotor. Each solution was run at full speed of 59,700 RPM for 90 to 100 minutes and pictures were taken usually at 2,5 , $10,20,30,40,50,60,80$, and 90 minutes after full speed of the rotor had been attained. As the rotor approached full speed pictures were taken also at 45,000 RPM and 57,000 RPM. Figure 2 shows the ultracentrifuge diagrams of the plasma protein solutions prepared by Methods A, B, C, F, and $S$. Column 1 represents pictures taken at the time the rotor had reached full speed, column 2 those taken 20 to 40 minutes after full speed and column 3 those taken 80 to 90 minutes after full speed. The upper diagram in each picture represents the solution heated for 10 hours at $60^{\circ} \mathrm{C}$. and the lower diagram the unheated control solution.

A very fast moving heterogeneous component appeared in all solutions heated for 10 hours at $60^{\circ} \mathrm{C}$. as the rotor neared full speed (arrow, upper diagrams, A1, B1, C1, F1, and S1). Very little was seen in the unheated solutions. The size of the component increased as the ethanol concentration and temperature used in preparation were decreased and increased, respectively (Method A to Method S).

Figure 2 shows that each of the unheated solutions had a small amount of fairly homogeneous material which appeared in the diagrams after the very fast moving component of the heated solutions had disappeared (arrow, lower diagrams, A2, B2, C2, F2, and S2). None of this component appeared in diagrams of heated solutions. It is suggested that during 10 hours' heating at 


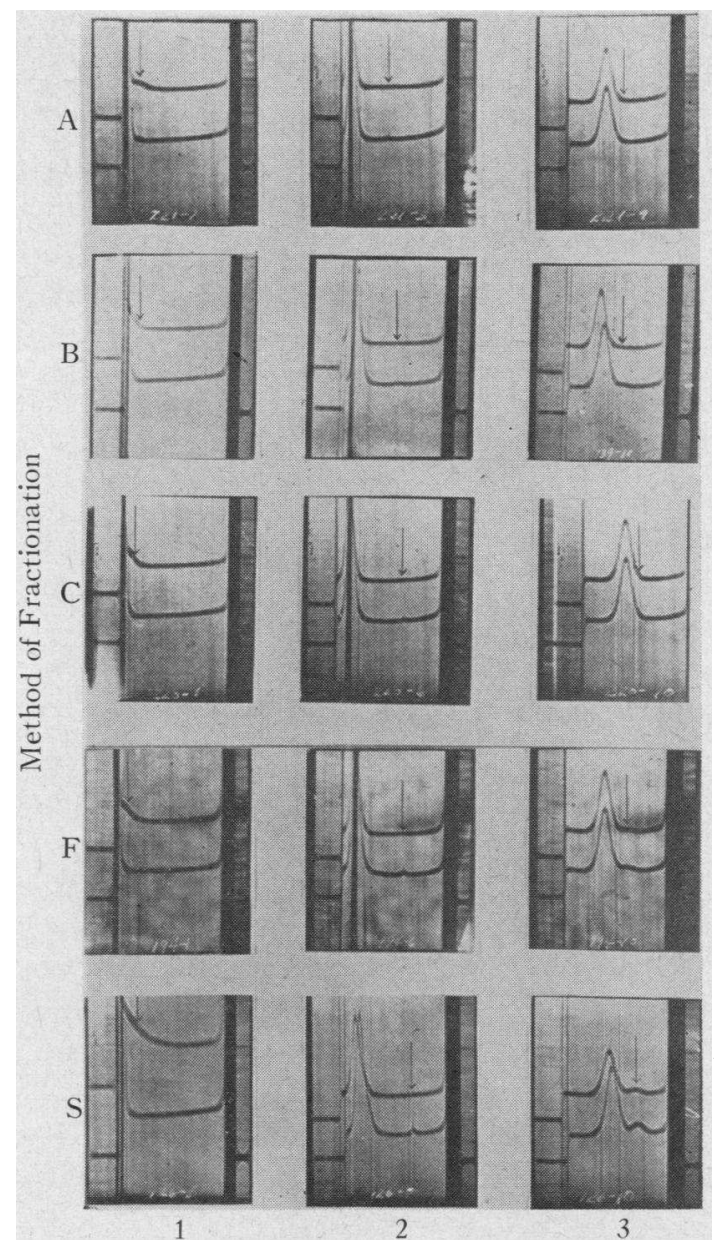

Fig. 2. The Ultracentrifugal Sedimentation Diagrams of the Plasma Protein Solutions

The upper diagram in each picture represents the heated solution, the lower the unheated solution. Pictures in column 1 were taken at the time the rotor reached full speed of 59,700 RPM, those in column 2, 20 to 30 minutes after full speed, and those in column 3, 80 to 90 minutes after full speed.

$60^{\circ} \mathrm{C}$. this component became part of the very fast moving material.

Later in the ultracentrifuge run another component appeared in both the heated and unheated samples of the $F$ and $S$ solutions (arrows, upper and lower diagrams, F3 and S3). This component was hardly discernible in the diagrams of the solutions prepared by Methods A, B, and C (arrows, $\mathrm{A} 3, \mathrm{~B} 3$, and $\mathrm{C} 3$ ). In the heated samples of $\mathrm{F}$ and $\mathrm{S}$ solutions this component was smaller than it was in the unheated samples. This difference suggests that during 10 hours' heating at $60^{\circ}$
C. a portion of this component became part of the very fast moving material.

The effect of 10 hours' heating at $60^{\circ} \mathrm{C}$. on the main component of the plasma protein solution is shown in Figure 2. The greatest effect was in the S solutions (upper diagram, S3). The main component in the $\mathrm{S}$ solutions following 10 hours heating at $60^{\circ} \mathrm{C}$. was markedly less than that of the unheated $\mathrm{S}$ solutions. The main components of the $\mathrm{A}, \mathrm{B}, \mathrm{C}$, and $\mathrm{F}$ solutions were less following heating for 10 hours at $60^{\circ} \mathrm{C}$. than they were in the unheated solutions. A rough calculation of the total areas of all components in both the heated and unheated solutions indicates that the size of the very fast heterogeneous component in heated solutions accounted for the decrease in area of each of the other components.

The extent to which the main component (Figure 2, A3, B3, C3, F3, and S3) was reduced when the solutions were heated for 10 hours at $60^{\circ} \mathrm{C}$. is shown in Table IV. The area of the main peak of each of the heated and unheated samples was determined from the ultracentrifuge pictures taken at 60, 80, and 90 minutes after the rotor had reached full speed of 59,700 RPM. The three areas of the main peaks of the heated solutions were averaged as were the three areas of the unheated solutions. The ratio of the average area of the main component in the heated solution to

TABLE IV

The effect of heating the plasma protein solutions for 10 hours at $60^{\circ} \mathrm{C}$. on the main component of the ultracentrifuge diagrams

\begin{tabular}{clccc}
\hline \hline & & \multicolumn{3}{c}{$\begin{array}{c}\text { Ratio of area of main component } \\
\text { (heated) to area of main } \\
\text { component (unheated) }\end{array}$} \\
\cline { 3 - 5 } Method & Stabilizer & $\begin{array}{c}\text { Prepara- } \\
\text { tion 1 }\end{array}$ & $\begin{array}{c}\text { Prepara- } \\
\text { tion 2 }\end{array}$ & $\begin{array}{c}\text { Prepara- } \\
\text { tion 3 }\end{array}$ \\
\hline A & None & 0.917 & 0.937 & 0.931 \\
& AT & 0.927 & 0.903 & 0.915 \\
& Cap & 0.911 & 0.972 & 0.915 \\
B & None & 0.778 & 0.909 & 0.901 \\
& AT & 0.943 & 1.000 & 1.005 \\
& Cap & 0.950 & 0.995 & 0.970 \\
C & None & 0.736 & 0.915 & 0.933 \\
& AT & 1.004 & 0.887 & 0.936 \\
& Cap & 0.881 & 0.964 & 0.751 \\
F & None & 0.678 & 0.965 & 0.907 \\
& AT & & 0.938 & 0.893 \\
& Cap & 0.763 & 0.880 & 0.988 \\
S & None & 0.409 & 0.627 & \\
& Non & & &
\end{tabular}


that in the unheated solution for each of several preparations made by Methods A, B, C, F, and S, is shown in Table IV.

The addition of either $0.008 \mathrm{M}$ sodium acetylDL-tryptophanate (AT) or $0.008 \mathrm{M}$ sodium caprylate (Cap) had no effect on the ultracentrifuge diagrams of the solutions heated for 10 hours at $60^{\circ} \mathrm{C}$. Table IV shows that the ratios of the areas of the main components of the heated versus the unheated solutions were essentially the same whether stabilizer was present or not.

\section{DISCUSSION}

Murray and Diefenbach ( 7 ) studied the effect of heating human plasma infected with the virus of serum hepatitis at $60^{\circ} \mathrm{C}$. for various periods of time. They found that when plasma was heated at $60^{\circ} \mathrm{C}$. for four hours or more there was an increase in turbidity and formation of a precipitate. van der Scheer, Wyckoff, and Clarke (8) found that when horse serum was warmed to about $65^{\circ}$ C. it went through steps of opalescence and cloudiness with an increase in viscosity and plasticity. Electrophoretic examination showed that a new component was formed when the horse serum was heated for 15 minutes at $65^{\circ} \mathrm{C}$. to $70^{\circ} \mathrm{C}$. They designated this component as the $\mathrm{C}$-component. Mobility was fairly constant in different preparations at approximately that of beta globulin. Evidence was presented that the C-component was formed at the expense of the albumin and the globulins. We have found that if all of the Fraction II + III proteins as well as the Fraction I proteins were not precipitated completely from plasma, the supernatant fluid following drying and reconstitution to plasma volume became cloudy and showed a new component in the electrophoresis apparatus following 10 hours' heating at $60^{\circ} \mathrm{C}$. The electrophoretic component was quite similar to that seen by van der Scheer, Wyckoff, and Clarke (8). It had a mobility equal to that of $\alpha_{2}$ globulin and was formed at the expense of both the albumins and globulins.

The amount of the component depended upon the conditions for precipitation of the Fraction II + III proteins. An ethanol concentration of 25 per cent at $-5^{\circ} \mathrm{C}$. (Method A) resulted in maximum precipitation of the Fraction II + III proteins and least of the new component in the electrophoresis. The conditions in Method F (20 per cent ethanol and $0^{\circ}$ C.) and Method $\mathrm{S}$ (11 per cent ethanol and $0^{\circ} \mathrm{C}$.) gave less precipitation and a greater amount of the new electrophoretic component following 10 hours' heating at $60^{\circ} \mathrm{C}$

The plasma protein solutions prepared by Method A showed less optical density change and less of the very fast moving component in the ultracentrifuge following 10 hours' heating at $60^{\circ}$ C. The solutions prepared by Methods F and S showed greater optical density changes and much more of the very fast moving component in the ultracentrifuge following heating. Both the $\mathrm{F}$ and $\mathrm{S}$ solutions were hazy after heating while the $\mathrm{A}, \mathrm{B}$, and $\mathrm{C}$ solutions were clear. The latter three remained clear after at least 50 hours' heating at $60^{\circ} \mathrm{C}$.

Studies concerning the effect of storage at various temperatures on the optical density of the plasma protein solutions following heating for 10 hours at $60^{\circ} \mathrm{C}$. are in progress. The optical density of both the stabilized and non-stabilized solutions changed very little after several months at $4^{\circ} \mathrm{C}$., room temperature, and $37^{\circ} \mathrm{C}$. Solutions prepared by Methods $\mathrm{A}, \mathrm{B}$, and $\mathrm{C}$ showed very little change in optical density after two to three weeks at $50^{\circ} \mathrm{C}$., while those prepared by Method $\mathrm{F}$ increased 0.04 after one week at $50^{\circ} \mathrm{C}$. Method $S$ solutions increased approximately 0.04 in optical density in 24 hours at $50^{\circ} \mathrm{C}$.

\section{SUM MARY}

1. Different ethanol concentrations and temperatures were used to remove the Fraction II + III proteins from human plasma in preparation of human plasma protein solutions.

2. When the ethanol concentrations were less than 25 per cent and the temperatures were higher than $-5^{\circ} \mathrm{C}$., the plasma protein solutions following 10 hours' heating at $60^{\circ} \mathrm{C}$. showed a new component in the electrophoresis patterns, an increased amount of a very fast moving component in the ultracentrifuge and a change in optical density.

3. When an ethanol concentration of 25 per cent and a temperature of $-5^{\circ} \mathrm{C}$. was used, the resulting plasma protein solution following 10 hours' heating at $60^{\circ} \mathrm{C}$. showed none of the new 
component in the electrophoresis patterns, much less of the very fast moving component in the ultracentrifuge and much less change in optical density.

4. The stabilizers, acetyl-DL-tryptophanate and caprylate, had little stabilizing effect on the solutions heated at $60^{\circ} \mathrm{C}$. for 10 hours.

\section{ACKNOWLEDGMENT}

The authors wish to express their gratitude to $\mathrm{Mr}$. Wayne Parker, Mr. Hugo Zee, Mr. Donald Warkenton, Mr. James Gillett, and Mr. Donald Williams for their assistance in the preparation of the solutions and the stability analyses. They also extend their thanks to Mr. Lewis Welton and Mrs. Josephine Salser for the ultracentrifuge work, and to Miss Helen Samaras, Pitman-Moore Company, Zionsville, Indiana, for the electrophoresis work.

\section{REFERENCES}

1. Mulford, D. J., Mealey, E. H., and Welton, L. D., Preparation of a stable human plasma protein solution. J. Clin. Invest., 1955, 34, 983.
2. Cohn, E. J., Strong, L. E., Hughes, W. L., Jr., Mulford, D. J., Ashworth, J. N., Melin, M., and Taylor, H. L., Preparation and properties of serum and plasma proteins. IV. A system for the separation into fractions of the protein and lipoprotein components of biological tissues and fluids. J. Am. Chem. Soc., 1946, 68, 459.

3. Scatchard, G., Strong, L. E., Hughes, W. L., Jr., Ashworth, J. N., and Sparrow, A. H., Chemical, clinical, and immunological studies on the products of human plasma fractionation. XXVI. The properties of solutions of human serum albumin of low salt content. J. Clin. Invest., 1945, 24, 671.

4. Ballou, G. A., Boyer, P. D., Luck, J. M., and Lum, F. G., The heat coagulation of human serum albumin. J. Biol. Chem., 1944, 153, 589.

5. Gornall, A. G., Bardawill, C. J., and David, M. M., Determination of serum proteins by means of the biuret reaction. J. Biol. Chem., 1949, 177, 751.

6. Mulford, D. J., and Mealey, E. H., Unpublished data.

7. Murray, R., and Diefenbach, W. C. L., Effect of heat on the agent of homologous serum hepatitis. Proc. Soc. Exper. Biol. \& Med., 1953, 84, 230.

8. van der Scheer, J., Wyckoff, R. W. G., and Clarke, F. L., An electrophoretic study of heated horseserum. J. Immunol., 1941, 40, 39. 